This item was submitted to Loughborough's Research Repository by the author.

Items in Figshare are protected by copyright, with all rights reserved, unless otherwise indicated.

\title{
States of transition: the femme fatale in the art of Fernand Khnopff and Leonor Fini
}

\section{PLEASE CITE THE PUBLISHED VERSION}

\section{PUBLISHER}

Ashgate Publishing Limited ( ) Michelle Facos and Thor J. Mednick and the contributors

\section{VERSION}

AM (Accepted Manuscript)

\section{PUBLISHER STATEMENT}

This work is made available according to the conditions of the Creative Commons Attribution-NonCommercialNoDerivatives 4.0 International (CC BY-NC-ND 4.0) licence. Full details of this licence are available at: https://creativecommons.org/licenses/by-nc-nd/4.0/

\section{LICENCE}

CC BY-NC-ND 4.0

\section{REPOSITORY RECORD}

Grew, Rachael V.. 2019. "States of Transition: The Femme Fatale in the Art of Fernand Khnopff and Leonor Fini”. figshare. https://hdl.handle.net/2134/20406. 
States of Transition: The Femme Fatale in the Art of Fernand Khnopff and Leonor Fini Rachael Grew

It is frequently noted, though rarely in very much detail, that Symbolism was an important precursor to Surrealism, particularly in its focus on interiority. ${ }^{1}$ This emphasis on interior states creates a clear bridge between Symbolism and Surrealism, which prized the unconscious and the irrational, and aimed to find the point at which dreams and reality merged together, thus ceasing to be opposites. The amalgamation of the dream and the real is evident throughout Symbolism: from Moreau’s highly detailed landscapes populated by mythical creatures, to Redon’s nightmarish monsters built on scientific principles of evolution, to the uncanny nature of Khnopff's disquietingly empty cities. ${ }^{2}$

The bridge between Symbolism and Surrealism is further strengthened through their shared obsession with the theme of Woman. Both movements took place during a point in time when the nature of Woman was starkly split into two socially constructed binary archetypes: the domestic goddess, or the passive muse, versus the sexual, castrating femme fatale. While the art created by both Symbolists and Surrealists frequently engaged with this binary, it was not always to confirm but rather to attempt to subvert it, and it is this subversion that also evidences Symbolism’s modernist credentials.

T. J. Clark has argued that nineteenth-century modernism could be defined by ambiguity: that an emphasis on uncertainty in technique and subject matter, which destabilized seemingly distinct categories of class identities and social spaces, reflected the "myth of modernity.”3 Griselda Pollock has built on this argument by stating that the spaces of modernity are those liminal spaces in which masculinity and femininity intersect and structure sexuality within a class hierarchy. ${ }^{4}$ She goes on to argue that Woman is constructed through the Baudelarian journey across ambiguous social spaces, moving from one type of femininity to another across 
the wife/whore or bourgeois/working class divide. ${ }^{5}$ Thus, ambiguity is essential to the modernist movement. However, because the Symbolists rejected an imitative art that replicated 'real' scenes, they did not depict these ambiguous social spaces in which gender identity was simultaneously formed and transgressed. The ambiguity of space which codified a woman's nature was instead transferred to Woman herself: she represented the modernist ambiguity and anxiety over the changing nature of gender 'types'. ${ }^{6}$

The nineteenth-century ideology of Woman as either nurturing housewife or fatal whore placed contemporary women in a rather difficult position. As Woman was held to be innately irrational, weak and immoral, even the most respectable wife and mother still retained the potential for baseness and depravity, making the 'positive' manifestation of this feminine polarity almost impossible to achieve. This biased dichotomy became in Symbolist hands an opposition between the angelic, idealized woman and the sexual destroyer. However, the Symbolist treatment of Woman was often much more complex, blurring these polarities of femininity, and sometimes even opposing genders. ${ }^{7}$ Indeed, even the apparent dualism of transcendent angel versus destructive temptress is a false one as, given the association of the mind and the spirit with the masculine, the angelic woman can engage in an erosion of gender boundaries through transcending the physical (and thus feminine) world for a stereotypically masculine realm, rendering her ambiguous.

Similarly, the binary archetype of Woman that was promoted during the nineteenth century persisted and strengthened in the twentieth. While women joined the labor force and worked at 'male' jobs during the World Wars, beforehand and afterwards they were expected to devote themselves to home, husband, and family on pain of otherwise being considered 'abnormal'. ${ }^{8}$ The depiction of Woman in Surrealist art is usually discussed within the boundaries of a similarly dichotomous idea of femininity: the inspirational but passive muse figure known as the femme enfant, and the castrating, sexually insatiable femme fatale. While the femme enfant in particular was meant to transgress conventional notions of femininity by celebrating the hedonistic, liberated and even insane woman, her passive, subordinate position to the male artist 
perpetuated the fundamental binary of the bourgeois Woman. However, there are several Surrealist artists who engaged with a more ambiguous notion of femininity. ${ }^{9}$ The task of this study is therefore threefold: to demonstrate the link between Symbolism and Surrealism by investigating the shared motif of the femme fatale; to discuss and ultimately evaluate the significance of the femme fatale as a tool of social subversion; and, through this analysis, to consolidate Symbolism's place within the history of modernism through its engagement with ambiguity.

Scholarly literature on the femme fatale frequently still generalizes her as the negative half of a feminine binary: she is the sexual temptress, the castrating destroyer; the polar opposite of the domesticated, passive woman (or muse) who is subservient to the needs of her man. ${ }^{10}$ In actual fact the femme fatale was much more complicated. Reinhold Heller has argued that the Symbolist femme fatale acted as a harbinger of life and even transcendence as well as of death and decay, and as such is more accurately described by the contemporary terms 'manly woman' or 'grim lady'. ${ }^{11}$ However, such a complex notion of the femme fatale is not singular to Symbolist art. There were a plethora of intricate and interlocking manifestations of the femme fatale across both high and low culture throughout the late nineteenth and early twentieth centuries, which incorporated the temptress, the fashionable lady, the New Woman, the androgyne and many other figures besides. ${ }^{12}$ Though I am unable to outline this elaborate web in more detail here, it suffices to say that the core concept of any incarnation of the femme fatale is ambiguity.

Looking specifically at the femme fatale, her ambiguity came in many forms. She may create gender ambiguity by dressing and/or behaving in a 'masculine' manner - such as by participating in male-dominated spheres such as politics and medicine. She may equally create class and moral ambiguity as, thanks to the rise in mass-produced, ready-to-wear clothing at the end of the nineteenth century, it became difficult to differentiate between a respectable, married lady and a well-dressed courtesan (in terms of appearance at least). ${ }^{13}$ However, with a bit of detective work these ambiguities could be resolved and the woman in question pinned down to a 
particular type, thus the anxiety caused by her potential to dissolve cultural boundaries could be defused. Yet, in cases where this ambiguity remained unsolved, the femme fatale was a terrifying threat to social order as she could not be classified within the constructed ideal of female gender types. It is this incarnation of the femme fatale, which I have labelled the abstruse femme fatale, which most accurately reflects the contemporary Symbolist term 'grim lady'. Thus, the woman who transgressed gendered spheres without resolution, who united creation and destruction, is referred to here as the abstruse femme fatale or grim lady.

But why specifically choose Khnopff and Fini to perform this analysis? A Belgian Anglophile and a cosmopolitan socialite do not perhaps seem like a compatible pair, yet both express an interest in hybrid, transitional states of being in their art. Khnopff sought enlightenment through isolation, evoking mental, meditative, even spiritual states in his work. This points to his subjects being located somewhere between the physical and the intangible; hybrids existing in a liminal state of transition. Fini also emphasized this transitional position because she evoked the dream, regeneration and awakening sexuality in her work, and she herself spoke of her preference for ambiguous states: androgyny, and the multiplicity afforded by dressing up. ${ }^{14}$ Moreover, both had an abiding interest in a particular manifestation of woman: mysterious and deadly, yet also creative; she was the epitome of the grim lady, the ambiguous, abstruse femme fatale.

Though Khnopff sometimes depicted the more typical stereotype of the sexual, destructive femme fatale, such as in his A Bewitching (c. 1912; private collection) much of his oeuvre was dedicated to an ambiguous form of Woman. ${ }^{15}$ Similarly, while Fini used many signifiers of the traditional, destructive femme fatale in her art, such as the sphinx, they were portrayed in such a way that blurs binary notions of 'good' and 'bad' femininity, thereby resulting in ambiguity. Given their shared interest in liminal states and moments of change, the transitional woman locked between two states - specifically the guardian and the woman-animal hybrid - will act as a focus for the comparison between Khnopff and Fini and their development of the abstruse femme fatale. 
Khnopff's woman-guardians may be regarded as abstruse femme fatales due to the way in which they blur bourgeois ideologies of gendered spheres. Equally, even if one ignores the fundamental ambiguity of the Symbolist angelic woman, Khnopff's women-guardians also incorporate contrasting traits that confuse their place within the binary. For instance, Khnopff's Victoria (1892, collection of Philip and Ellen Serck) depicts a female knight who has apparently cut off her long, red hair. This severance, combined with her golden laurel wreath, symbolizes her triumph over sensuality, since long, flowing hair - particularly red hair - was a common contemporary motif for representing the enticing snares of the sexual destroyer. ${ }^{16}$ This idea is reinforced by the way in which the armor hides the feminine curves of the knight's body. By removing herself from the fleshy, physical world emblematized by her hair, this knight subverts contemporary notions of Woman, both bourgeois and Symbolist, as even the most idealized domestic goddess or angelic muse was ultimately rooted in the physical. Instead she has transgressed to the more masculine realm of thought and the intangible. Moreover, any sense of her purified, transcendent nature is undermined by the fact that she can be allied with battle and bloodshed - for instance Victoria, the Roman goddess of battle. For all her signifiers of femininity she is a masculine woman and, because of the lack of contextual detail that might otherwise serve to ‘decode’ her and put her in her place, she remains ambiguous.

Not all of Khnopff's guardian figures wear armour; there is also the interesting example of the sword-wielding Solitude (c. 1890-91; Neumann foundation, Gingins, Switzerland), which forms the central panel of Khnopff's Isolation triptych (c.1890-94). ${ }^{17}$ Francisca Vandepitte notes that Khnopff followed the tradition of fifteenth-century altarpieces by using grey tones for the triptych's outer wings in order to suggest physical reality so that the use of color for the central panel emphasized the glory of the spiritual. ${ }^{18}$ The two outer panels depict two binary female figures taken from Edmund Spencer's sixteenth-century epic poem The Faerie Queen: Arcasia, with her long, billowing hair, represents the sexual temptress, while Britomart, clad in armour, is the virginal female warrior on the hunt for a husband. By specifically placing Solitude between these two stereotypes of womanhood, Khnopff makes her decidedly ambiguous. ${ }^{19}$ Moreover, 
because she is linked with both the spiritual, through the use of the fifteenth-century altarpiece format, and the bloody, because she holds a sword to defend her isolation, Solitude, like Victoria, transgresses into the masculine worlds of contemplative interiority and violence.

One may also link Solitude to sterility. The figure in the bubble at the bottom of the panel recreates the pose of the woman in Khnopff's I Lock the Door Upon Myself (1891; Neue Pinokothek, Munich) suggesting the sacrifice of 'normal' female relations to a contemporary viewer since, by isolating herself, she cannot participate in either childbearing or seduction: the hallmarks of the bourgeois wife/whore female binary. ${ }^{20}$ Instead she is linked to an alternative form of creation - namely artistic creation. This is implied firstly through the tiny bust of Hypnos, god of sleep, at the top of the vase in the lower right corner. If art is intrinsically related to dreams, as Khnopff suggested, then the presence of Hypnos implies artistic creation. Secondly, as Khnopff himself advocated isolation as a means of achieving one’s creative potential, the woman's voluntary removal of herself from society again suggests the desire to create art. Moreover, as both the creative process and the artist is typically gendered male this implies that the woman, through her connection with artistic creativity, blurs gender boundaries. ${ }^{21}$ Even if she were to be viewed as the more acceptably feminine muse this does not resolve the issue that her creative function is not a pro-creative one; she is autonomous and selfsufficient, which renders her androgynous and unfathomably ambiguous. The woman-guardian's autonomy and her alternative creativity are all issues that emerge later in depictions of armoured women-guardians by Fini.

Fini’s guardians do not relinquish their sensuality. Moreover, they actively protect something (or someone) rather than standing as a passive display. This is particularly noticeable in The Alcove: An Interior with Three Women, otherwise known as The Black Room, 1939 (fig. $\mathrm{X}-1$ ). Here two women lounge on a shadowy bed, while another woman wearing an armoured breastplate stands at attention in the foreground. This woman is Fini's friend and fellow Surrealist artist Leonora Carrington, whom she described as a "true revolutionary." ${ }^{22}$ It is Carrington's role within the work that creates a sense of ambiguity - she appears to be guarding 
the bed, but from what? Is she protecting the women, or is she ensuring they remain where they are, and if so, why? In usurping the power of the male through Carrington's active role as a guardian, while keeping her intentions and motives unclear, Fini blurred social constructs of gender and made Carrington’s character indefinable.

The Shepherdess of the Sphinxes (1941; Guggenheim Museum, New York) is also an intriguing work in this context. In contrast to Khnopff's knights, the sensuality of the shepherdess is emphasized by her armour, which barely covers her abdomen and pudenda, forming a sort of chastity belt. While this might imply virginity, the way in which she straddles her shepherd's crook is highly suggestive, creating a connection not only to the witch's broom and thereby to the debauched sexuality of the Black Mass, but also to sexual autonomy. Similarly, the shepherdess herself may be allied with sterility due to the vaginal shield of her armour, and furthermore the sphinxes who lounge around her are usually connected with death and destruction: something seemingly emphasized by the severed flower heads, bones and eggshells littered on the ground. Yet, these items are part of a natural cycle of life and death; in being destroyed they pave the way for regeneration, again suggesting a non-procreative form of creation. ${ }^{23}$ The shepherdess's lack of engagement with 'normal' reproduction casts her as a 'nonwoman' in the eyes of society, rendering her ambiguous. Thus both Khnopff and Fini problematize gender boundaries through creating a vision of woman who embodied a liminal, unsignifiable femininity. However, while Khnopff achieved this by removing the woman's sexuality, Fini created the same effect through emphasizing it.

The sphinx was a key motif for both Khnopff and Fini and therefore ranks as one of the most important of their woman-animal hybrids. While Khnopff frequently portrayed the sphinx in her stereotypical role as seductive destroyer, his 1889 work An Angel (fig. X-2), which illustrates a female knight subduing a sphinx-like woman-tiger, is something different. Following an interview with the artist, Maria Biermé confirmed that this image refers to the struggle between idealism, represented by the knight, and materialism, embodied by the sphinx. ${ }^{24}$ Yet is this struggle necessarily being played out by two opposing entities? 
Jeffrey Howe has suggested that the fact that the sphinx is smiling implies she masochistically enjoys being conquered. Thus, the destructive passion usually personified by the sphinx is redirected from the exterior to the interior. Physical sensuality becomes spiritual, with intellectual passion emblematized by the knight. ${ }^{25}$ One the one hand, this makes the knight ambiguous by removing her from the physical realm of the 'normal' woman, but also suggests that the capacity for passion remains; thereby making her spiritual status uncertain; she hovers on the border between states. Similarly, if the sphinx is masochistic in her enjoyment of being dominated then - while this can be linked to nineteenth-century views on sexual degeneracy - it was at least a feminine form of 'deviant' behavior, given its emphasis on passivity. ${ }^{26}$ Both figures therefore have traits relating to each other: the knight retains her passionate potential, while the sphinx moves towards a 'natural' female passivity, rendering both figures socially indeterminate.

Fini's sphinxes are equally liminal because she consistently placed them in landscapes of putrefying vegetation, thereby linking them with the new life that springs from decay, and consequently indicating ambiguity. ${ }^{27}$ This is furthered by works such as Sphinx Amalburga (fig. X-3), which depicts a sphinx embracing a nude man, her hands around his neck; significantly, whether this is a tender, loving gesture or the prelude to a violent act is unclear. Though 'amalburga' means 'protector' and Fini also considered 'Sphinx Amoureux' as the title for the work, André Pieyre de Mandiargues, a writer and friend of Fini’s, described the sphinx as: “watching [the man] with a slightly absentminded and disturbing tenderness."28 Indeed, Fini meant for the sphinx to remain ambiguous, ultimately tying this hybrid creature to the abstruse femme fatale. ${ }^{29}$ Though both Khnopff and Fini illustrate the ambivalent nature of the sphinx, in Khnopff's work this is achieved through the positive influence of another, idealized entity, whereas Fini allowed the sphinx much more autonomy.

A more complex example of the woman-animal hybrid in these artists' works is the birdwoman. Most unusually, Khnopff's Sleeping Medusa (fig. X-4) depicts the gorgon as a birdwoman, and a rather androgynous one at that as she has no hair, only feathers. This in itself 
complicates the typical reading of Medusa, whose serpentine coiffure is the logical extreme of the sinuous tendrils of hair shown snaking from the heads of the 'typical', sexually destructive femme fatale. However, another way of reading Khnopff's Medusa - as an abstruse femme fatale - is offered by her closed eyes. Because Medusa was able to turn a man to stone with a single glance, one could argue that the source of men's fear of her was that she could deprive them of their status as active subjects by making them into passive objects, thus feminizing them and disturbing the patriarchal order. By depicting her with closed eyes and apparently at rest, Khnopff reduced this source of anxiety, making her passive and therefore more acceptably feminine. However, Medusa has not been blinded, nor has she been killed, so she retains the power to 'destroy' men, just as the knight of An Angel retains at least the capacity for passion. Like Fini’s sphinxes, the viewer is left uncertain as to Medusa's intentions and it is her potential to usurp male power while remaining ambiguous that distinguishes her as an abstruse femme fatale.

The bird-human hybrid appears several times in Fini’s work, and she herself frequently dressed up in feathered costumes for exclusive fancy-dress balls, making herself a human-animal hybrid and, one could argue, an abstruse femme fatale. The clearest example of this is to be found in perhaps her most famous fancy-dress outfit: the owl costume she wore for the Ball of the Birds in Paris in 1948 (fig. X-5). Fini was a central figure in contemporary high society and was discussed frequently in gossip columns. Her owl costume featured on the front cover of This Week Magazine, and the mask she wore as part of the outfit inspired the ending of Paula Réage’s erotic novel The Story of $O .^{30}$ In the posed photographs of Fini in this costume, she specifically seeks to make connections with the witch through referring to two major animal signifiers of this archetype: the owl, and the black cat. In one such photograph, we see her holding a cat, very possibly Marmifone, one of her three beloved Persian cats. Despite the fact that another of this 'fluffy troop’, Moutchi, was her favourite, Marmifone was the only black cat of the group, suggesting that Fini specifically wanted to suggest a connection to witches. ${ }^{31}$ Though the witch is a femme fatale figure usually interpreted in a one-dimensional manner as an evil hag, Fini 
admired Jules Michelet's novel The Witch, which portrays witches more positively. Fini viewed Michelet's witch as the embodiment of "beauty, rebellion and knowledge," suggesting the witch's ambivalent nature since all these qualities can be used to both good and bad ends. ${ }^{32}$ For Fini, the witch, like the sphinx, represented power and autonomy and blurred the boundaries between 'types' of femininity, thereby signifying ambiguity. ${ }^{33}$ In these particular examples of bird-women, therefore, both Khnopff and Fini re-evaluated stereotypically monstrous women, portraying them in a more complex manner. Yet, the anxiety over the power wielded by such figures is palpable in Khnopff's work, as he rendered Medusa safely passive, but in Fini’s work such power was to be celebrated and emphasized.

Thus, the way in which Khnopff's and Fini's women hover on the borders between constructed signifiers of gender, inhabiting hybrid and transitional states, demonstrates not only the interconnection between Symbolism and Surrealism, but also that modernist ambiguity is inherent in Symbolist art through the motif of Woman. Though the essential ambiguity of the abstruse femme fatale remained intact, her expression nevertheless was transformed in the art of Khnopff and Fini through their emphasis on different gendered spheres. Khnopff's abstruse femmes fatales are linked in one way or another to the intangible; an ethereal realm of thought, mind and spirituality - they transgress into a masculine domain. Fini's 'grim ladies' by contrast retain and loudly proclaim their sexuality, their independence, and their power, locating them squarely in the physical realm. Thus a woman's place in the world and her attitude to that placement is re-evaluated by both Khnopff and Fini, but with an emphasis on contrasting spheres. In this way, perhaps we can say that both artists engage with modernist space as conceived by Pollock after all. Though they do not depict café-concerts or theatres, these binary spaces become modern through the way in which they facilitate a transgression of gender boundaries: they enable the intersection of masculinity and femininity. Though this approach may heighten the ambiguity of the femme fatale within her social context, it ultimately fails to subvert fully the culturally constructed notion of Woman, because she is still located within binary notions of space. She disrupts social constructs of femininity, but does so only in relation 
to the gendered connotations of the interior/exterior, the physical/intangible. The archetype of the femme fatale is here used as a catalyst for the deconstruction of cultural signs, yet, though she cannot fully be decoded, the power of her ambiguity and the anxiety it generates within patriarchal culture is contained, caged within a binary discourse. In the end, it is the femme fatale's potential for cultural disobedience that accords this fragile kind of power, and it is this potential that both Khnopff and Fini explore in their art.

\footnotetext{
${ }^{1}$ This article was made possible by a grant from the Scouloudi Foundation in association with the Institution of Historical Research. I explore the links between Symbolism and Surrealism in detail in my Ph.D. thesis "The Evolution of the Alchemical Androgyne in Symbolist and Surrealist Art”, (Ph.D. diss., University of Glasgow, 2010). The most recent text to explore Symbolism and Surrealism is Natalie Aubert, P.-P. Fraiture, and Patrick McGuinness, eds., From Art Nouveau to Surrealism: Belgian Modernity in the Making (London: Legenda, 2007). However, in addition to limiting its scope to Belgium, the text moves from one movement to the other with very little discussion about the relationship between the two.

2 The emphasis on interiority can most clearly be found in Albert Aurier’s 1891 "Symbolism in Painting," Euvres Posthumes (Paris, 1893), 215-16, translated and reprinted in abridged form in French Symbolist Painters: Moreau, Puvis de Chevannes, Redon and their Followers (London: Arts Council of Britain, 1972), 165. It is also expressed by Khnopff, as Frederic Leen has shown in his essay “'Like Long Echoes From Afar that Melt into a Unity Deep and Dark'. Fernand Khnopff and Symbolism”, Fernand Khnopff (Brussels: Royal Museums of Fine Art of Belgium, 2004), 23. However, it should be noted that despite the co-existence and interaction of the dream and the real within the work of these Symbolist artists, they still accorded the dream higher status than the real; their aim was ultimately to transcend the latter for the former, not combine the two.
}

${ }^{3}$ T. J. Clark, The Painting of Modern Life: Paris in the Art of Manet and his Followers (London: Thames and Hudson, 1985), 259. This argument is explored in more depth throughout this text.

${ }^{4}$ Griselda Pollock, Vision and Difference: Femininity, Feminism and the Histories of Art (London-New York: Routledge, 1988), 70.

${ }^{5}$ Ibid, 72.

${ }^{6}$ The anxiety of the perceived blurring of gender boundaries is evident in contemporary scientific and psychological discourse that specifically links degeneration with gender elision. See for example Richard von Krafft-Ebing, Psychopathia Sexualis (12th edition, 1903), trans. Franklin S. Klaf (New York: Arcade Publishing, 2011). 
${ }^{7}$ See Reinhold Heller, “Some Observations Concerning Grim Ladies, Dominating Women, and Frightened Men around 1900" in Reinhold Heller, ed., The Earthly Chimera and the Femme Fatale: Fear Of Woman in NineteenthCentury Art, (Chicago: University of Chicago Press, 1981), 8-13.

${ }^{8}$ Joan Riviere’s 1929 essay “Womanliness as Masquerade,” written during the heyday of Surrealism, notes the anxiety felt by both men and women over the latter behaving in a masculine way, and articulates the very concept of femininity in terms of the domestic sphere. See Joan Riviere, "Womanliness as Masquerade" (1929) in Victor Burgined., Formations of Fantasy (London: Methuen, 1986), 35-44.

${ }^{9}$ These artists are largely female. Some male artists present women as powerful figures but often they are ultimately passive and/or catalysts for male development. See for instance the motif of the female hysteric as discussed in David Lomas, The Haunted Self: Surrealism, Psychoanalysis, Subjectivity (New Haven; London: Yale University Press, 2000).

${ }^{10}$ See for example Bram Dijkstra, Idols of Perversity: Fantasies of Feminine Evil in Fin de Siècle Culture (Oxford: Oxford University Press, 1986). More recently, Rosina Neginsky refers to a binary view of Woman within Symbolism. Rosina Neginsky, "Introduction” in Rosina Neginsky, ed., Symbolism, Its Origins and Its Consequences (Cambridge: Cambridge Scholars Press, 2010), 7.

${ }^{11}$ Heller, 11-12. Barbara Larson has also noted a more nuanced approach to the femme fatale in her essay "Darwin’s Sexual Selection and the Jealous Male in Fin-de-Siècle Art” in Barbara Larson and Fae Brauer, ed., The Art of Evolution: Darwin, Darwinisms and Visual Culture (Hanover: Dartmouth College Press, 2009), 173-93. Here, she argues that, in the work of some Symbolists, the femme fatale refers to the artist's own psychological trauma; feelings of sexual jealousy and loss. Interestingly this may provide another link to Surrealism, as Amy Lyford has previously discussed how certain Surrealists used the female body as a locus for displaced psychological and physical trauma caused by the Great War. See Amy Lyford, Surrealist Masculinities. Gender Anxiety and the Aesthetics of Post-World War I Reconstruction in France (Berkeley; L. A.; London: University of California Press, 2007).

${ }^{12}$ For critical discussions challenging the stereotyped binary of the femme fatale see Elizabeth K. Menon, Evil by Design: The Creation and Marketing of the Femme Fatale (Chicago: University of Chicago Press, 2006) and Helen Hanson, and Catherine O’Rawe ,eds., The Femme Fatale: Images, Histories, Contexts, (Basingstoke, UK: Palmgrove Macmillan, 2010).

${ }^{13}$ Menon discusses this more complex ambiguity in connection with the prostitute, and by extension the fashionable Parisienne, but her focus on pop culture means she does not discuss the more mythic or symbolic women of Khnopff and his contemporaries. 
${ }^{14}$ Leonor Fini, “Mes Théâtres”, Corps écrit 10 (1984): 31-3. I have previously discussed the ambiguous nature of Fini's female figures in my article 'Sphinxes, Witches and Little Girls: Reconsidering the Female Monster in the Art of Leonor Fini’ in Elizabeth Nelson, Jillian Burcar, and Hannah Priest, eds., Monsters and the Monstrous: Myth and Metaphors of Enduring Evil (Oxford: Interdisciplinary Press, 2010), 97-106. However, this article focuses on the monstrous female, pathenogenesis and the subversion of the Surrealist femme enfant/femme fatale binary, rather than exploring ambiguity in connection to the Symbolist concept of the grim lady, or the relationship between ambiguity and Modernism.

${ }^{15}$ S. Wilson, “Fernand Khnopff. Brussels, Salzburg, and Boston,” The Burlington Magazine 146 (2004): 423.

${ }^{16}$ Khnopff also directly treats this subject in Hair (1892, Collection of the Communauté française de Belgique.). Interestingly, Larson also notes the Darwinian argument for long hair as a sexual characteristic in women, though she examines Munch rather than Khnopff in this context. See Larson, 186.

${ }^{17}$ The triptych is split into its individual panels. Only Isolation is at the Neumann foundation; the monochrome Arcasia and Britomart wing panels, both of 1892, are owned by the Collection of the Communauté française de Belgique.

${ }^{18}$ Francesca Vandepitte, “Isolation” in Frederic Leen, ed., Fernand Khnopff, (Brussels: Royal Museums of Fine Art of Belgium, 2004), 172.

19 Ibid.

20 Ibid.

${ }^{21}$ Much has been written on the masculinisation of the artist, the practice of art, and the canon. One of the most fundamental texts on this topic remains Roszika Parker and Griselda Pollock, Old Mistresses: Women, Art, and Ideology (London: Woman’s Press), 1981.

${ }^{22}$ Whitney Chadwick, Women Artists and the Surrealist Movement (London: Thames and Hudson, 1985), 82.

${ }^{23}$ This ambiguous approach to nature is noted by Whitney Chadwick. See Chadwick, 1985, 188.

${ }^{24}$ Maria Biermé, “Fernand Khnopff,” La Belgique Artistique et Littéraire, vol. 8 (1907): 100, translated and cited in Jeffrey Howe, The Symbolist Art of Fernand Khnopff, (Ann Arbor, Michigan: UMI Research Press, 1979), 42-3.

${ }^{25}$ Howe, 43.

${ }^{26}$ Krafft-Ebing, 130.

${ }^{27}$ The ambiguity of Fini's sphinxes has previously been noted by Xavière Gauthier, Peter Webb and Whitney Chadwick among others. However, they do not link these sphinxes to the Symbolist abstruse femme fatale, nor do they connect the ambiguity of the sphinx to the discourse on Modernist art.

${ }^{28}$ Peter Webb, Sphinx: The Life and Art of Leonor Fini (New York: Vendome, 2009), 99. 
${ }^{29}$ Ibid.

${ }^{30}$ Ibid, 127.

${ }^{31}$ Ibid, 120.

${ }^{32}$ Ibid, 49.

${ }^{33}$ For more details on this topic see Grew 2010, 97-106. 